\title{
Novel 1,4-naphthoquinone derivatives induce reactive oxygen species-mediated apoptosis in liver cancer cells
}

\author{
YUE WANG $^{1 *}$, YING-HUA LUO ${ }^{2 *}$, XIAN-JI PIAO ${ }^{3 *}$, GUI-NAN SHEN $^{1}$, LING-QI MENG ${ }^{1}$, \\ YI ZHANG $^{1}$, JIA-RU WANG ${ }^{1}$, JIN-QIAN LI ${ }^{1}$, HAO WANG ${ }^{1}$, WAN-TING XU ${ }^{1}$, YANG LIU ${ }^{1}$, \\ YU ZHANG ${ }^{1}$, TONG ZHANG ${ }^{1}$, SHI-NONG WANG ${ }^{1}$, HU-NAN SUN ${ }^{1}$, YING-HAO HAN ${ }^{1}$, \\ MEI-HUA JIN ${ }^{1}$, YAN-QING ZANG ${ }^{4}$, DONG-JIE ZHANG ${ }^{4}$ and CHENG-HAO JIN ${ }^{1}$
}

\begin{abstract}
${ }^{1}$ Department of Biochemistry and Molecular Biology, College of Life Science and Technology; ${ }^{2}$ Department of Grass Science, College of Animal Science and Veterinary Medicine, Heilongjiang Bayi Agricultural University, Daqing, Heilongjiang 163319;

${ }^{3}$ Department of Gynaecology and Obstetrics, The Fifth Affiliated Hospital of Harbin Medical University,

Daqing, Heilongjiang 163316; ${ }^{4}$ Department of Food Science and Engineering, College of Food Science, Heilongjiang Bayi Agricultural University, Daqing, Heilongjiang 163319, P.R. China
\end{abstract}

Received March 29, 2018; Accepted November 15, 2018

DOI: $10.3892 / \mathrm{mmr} .2018 .9785$

\begin{abstract}
Derivatives of 1,4-naphthoquinone have excellent anti-cancer effects, but their use has been greatly limited due to their serious side effects. To develop compounds with decreased side effects and improved anti-cancer activity, two novel types of 1,4-naphthoquinone derivatives, 2,3-dihydro-2,3-epoxy-2-propylsulfonyl-5,8-dimethoxy-1,4-naphthoquinone (EPDMNQ) and 2,3-dihydro-2,3-epoxy-2-nonylsulfonyl-5,8-dimethoxy-1,4-naphthoquinone (ENDMNQ) were synthesized and their anti-tumor activities were investigated. The effects of EPDMNQ and ENDMNQ on cell viability, apoptosis and accumulation of reactive oxygen species (ROS) in liver cancer cells were determined by MTT cell viability assay and flow cytometry. The expression levels of mitochondrial, mitogen activated protein kinase (MAPK) and signal transducer and activator of transcription 3 (STAT3) signaling pathway-associated proteins in Hep3B liver cancer cells were
\end{abstract}

Correspondence to: Professor Cheng-Hao Jin, Department of Biochemistry and Molecular Biology, College of Life Science and Technology, Heilongjiang Bayi Agricultural University, 5 Xinfa Street, Daqing, Heilongjiang 163319, P.R. China

E-mail: jinchenghao3727@qq.com

Professor Dong-Jie Zhang, Department of Food Science and Engineering, College of Food Science, Heilongjiang Bayi Agricultural University, 5 Xinfa Street, Daqing, Heilongjiang 163319, P.R. China

E-mail: byndzdj@126.com

*Contributed equally

Key words: 1,4-naphthoquinone derivatives, hepatocellular carcinoma cells, apoptosis, reactive oxygen species, mitogen-activated protein kinase, signal transducer and activator of transcription 3 analyzed by western blot analysis. The results demonstrated that EPDMNQ and ENDMNQ inhibited the proliferation of liver cancer Hep3B, HepG2, and Huh7 cell lines but not that of normal liver L-02, normal lung IMR-90 and stomach GES-1 cell lines. The number of apoptotic cells and ROS levels were significantly increased following treatment with EPDMNQ and ENDMNQ, and these effects were blocked by the ROS inhibitor $N$-acetyl-L-cysteine (NAC) in Hep3B cells. EPDMNQ and ENDMNQ induced apoptosis by upregulating the protein expression of $\mathrm{p} 38$ MAPK and c-Jun N-terminal kinase and downregulating extracellular signal-regulated kinase and STAT3; these effects were inhibited by NAC. The results of the present study demonstrated that EPDMNQ and ENDMNQ induced apoptosis through ROS-modulated MAPK and STAT3 signaling pathways in Hep3B cells. Therefore, these novel 1,4-naphthoquinone derivatives may be useful as anticancer agents for the treatment of liver cancer.

\section{Introduction}

Liver cancer is one of the leading causes of cancer-associated mortality in worldwide (1). Patients suffering from this disease are often diagnosed with late-stage cancer and severely impaired liver function. Due to the poor response to hepatic resection, patients may only be able to be treated with chemotherapy (2). At present, the primary chemotherapeutic drugs for liver cancer are shikonin, 5-fluorouracil (5-FU) and cisplatin, but these drugs have severe side effects and are expensive $(3,4)$. Therefore, novel therapeutic agents with improved efficiency and lower toxicity are urgently required for liver cancer.

Apoptosis is an active form of chemotherapy-induced cell death characterized by orderly cell death, and is mediated by mitochondrial dysfunction. The caspase cascade serves an important role in this process (5). The B-cell lymphoma 2 (Bcl-2) family consists of proteins that either promote or inhibit apoptosis. Inhibiting anti-apoptotic protein $\mathrm{Bcl}-2$ and promoting pro-apoptotic protein $\mathrm{Bcl}-2$-associated $\mathrm{X}$ protein 
(Bax) expression can be targeted for cancer chemoprevention (6). Caspase-3 is one of the most important molecules in the regulation of apoptosis and cell survival, and exists as an inactive enzyme that undergoes proteolytic cleavage at conserved aspartic residues, to produce large and small subunits that dimerize to form the active enzyme (7).

The mitogen-activated protein kinase (MAPK) pathway is activated by upstream genomic events and/or activation of multiple signaling events where information coalesces at this important nodal pathway point (8). The p38 MAPK pathway is an important regulator of a number of cellular responses. It is well established that enhanced p38 activity correlates with a poor clinical prognosis in certain tumor types (9-11). The c-Jun N-terminal kinase (JNK) is a master protein kinase that regulates a number of physiological processes including inflammatory responses, morphogenesis, and cell proliferation, differentiation, survival and death $(12,13)$. Extracellular signal-regulated kinase (ERK) phosphorylation results in the activation of multiple substrates that are responsible for stimulating cell proliferation (14). In addition, signal transducer and activator of transcription 3 (STAT3) is persistently activated in several types of cancer, and also regulates numerous cardinal features of cancer, including cancer cell growth, apoptosis, metastasis and tumor angiogenesis $(15,16)$. In addition, the protein expression level of STAT3 in HCC tissues was identified to be increased compared with that in normal liver and adjacent tissues (17).

Reactive oxygen species (ROS) within cells including hydrogen peroxide, superoxide anions and hydroxyl radicals serve as second messengers in the regulation of a number of important cellular events including transcription factor activation, gene expression and cellular proliferation, differentiation and senescence $(18,19)$. In addition to endogenous sources of ROS, ROS levels may also increase due to chemical stimulation, ultraviolet radiation and thermal exposure (20). ROS have also been implicated in the metabolic reprogramming of cancer cells, serving important roles in tumor initiation, progression and metastasis (21). Excessive production of ROS leads to disruption of the homeostasis of the intracellular redox status, which may directly induce oxidative damage in lipids, proteins and nucleic acids, thereby killing cancer cells by disturbing their metabolism and signal transduction (22). In addition, based on the different redox status of normal and cancer cells, a promising therapeutic strategy based on drugs that increase ROS generation and induce apoptosis in cancer cells has arisen cancer therapy (23).

As naphthalene organic derivatives, 1,4-naphthoquinone compounds have been extensively investigated for their potential biological benefits, including their anti-inflammatory and anti-bacterial activities (24). In addition, the 1,4-naphthoquinone pharmacophore exhibits anti-cancer activity and has been the focus of previous studies $(25,26)$. Among the 1,4-naphthoquinone compounds, plumbagin, mitomycin and shikonin have been used in the development of potent anti-cancer drugs (27). However, these compounds exhibit high levels of cytotoxicity and significant side effects, making their application as anti-cancer drugs in the clinical setting problematic (28). Therefore, our previous study used 1,4-naphthoquinone as a common compound to synthesize novel naphthoquinone derivatives, which indicated significantly improved cytotoxicity and increased anti-tumor activity in several types of cancer cells $(29,30)$.

In an attempt to develop compounds with decreased side effects and optimized antitumor effects, two novel types of 1,4-naphthoquinone derivatives were synthesized, namely 2,3-dihydro-2,3-epoxy-2-propylsulfonyl-5,8-dimethoxy-1,4-naphthoquinone (EPDMNQ) and 2,3-dihydro-2,3-epoxy-2-nonylsulfonyl-5,8-dimethoxy-1,4-naphthoquinone (ENDMNQ). Then, their effects on anti-proliferation, apoptosis induction and ROS generation in liver cancer cells were detected. The molecular mechanisms of apoptosis induced by EPDMNQ and ENDMNQ were also explored in Hep3B cells.

\section{Materials and methods}

Synthesis of the 1,4-naphthoquinone derivatives EPDMNQ and $E N D M N Q . \mathrm{AlCl}_{3}(142 \mathrm{~g}, 1.06 \mathrm{~mol})$ and $\mathrm{NaCl}(28.3 \mathrm{~g}$, $0.48 \mathrm{~mol}$ ) were melted at $150-155^{\circ} \mathrm{C}$, and a mixture of 1,4-dimethoxybenzene $(0.12 \mathrm{~mol})$ and maleic anhydride ( $0.24 \mathrm{~mol})$ was added to the melted mixture. The temperature was sustained at $170-175^{\circ} \mathrm{C}$ for $1-2$ min and the dark red melt was allowed to cool. Next, the distilled water $(1,400 \mathrm{ml})$ and $98 \% \mathrm{HCl}(100 \mathrm{ml})$ were added to the melt mixture and continuously mixed for $12 \mathrm{~h}$ to generate naphthazarin. The mixture of naphthazarin $(19.0 \mathrm{~g})$, tetrahydrofuran $\left(\mathrm{C}_{4} \mathrm{H}_{8} \mathrm{O} ; 200 \mathrm{ml}\right)$, $\mathrm{Na}_{2} \mathrm{~S}_{2} \mathrm{O}_{4}(10.6 \mathrm{~g})$, distilled water $(200 \mathrm{ml})$ and tetrabutylammonium bromide $\left(\mathrm{C}_{16} \mathrm{H}_{36} \mathrm{BrN}, 2.0 \mathrm{~g}\right)$ were mixed for $1 \mathrm{~h}$. Then, a solution of $\mathrm{C}_{2} \mathrm{H}_{6} \mathrm{O}_{4} \mathrm{~S}(25 \mathrm{ml}), \mathrm{NaOH}(40 \mathrm{ml})$ and $\mathrm{Na}_{2} \mathrm{~S}_{2} \mathrm{O}_{4}$ $(10.6 \mathrm{~g})$ were added to the mixture stirred for $22 \mathrm{~h}$ at room temperature. The 1,4,5,8-tetramethoxynaphthalene was then recovered by filtration and recrystallized from petroleum ether (boiling point $90-120^{\circ} \mathrm{C}$ ). The residue was recrystallized from $\mathrm{MeOH}$ to give the title compound 5,8-dimethoxy-1,4-naphthoquinone (DMNQ) The 1-Mercaptopropane $(1.65 \mathrm{mmol})$ and 1-Nonanethiol (1.65 mmol) was added to a solution of DMNQ $(1.38 \mathrm{mmol})$ and $\mathrm{MeOH}(30 \mathrm{ml})$ respectively. The mixture was then stirred at room temperature for $4 \mathrm{~h}$. A solution of sodium dichromate $\left(\mathrm{Na}_{2} \mathrm{Cr}_{2} \mathrm{O}_{7} \cdot 2 \mathrm{H}_{2} \mathrm{O}, 0.76 \mathrm{mmol}\right)$ and $98 \% \mathrm{H}_{2} \mathrm{SO}_{4}$ $(0.23 \mathrm{mmol})$ was then added and stirred for $2 \mathrm{~min}$. The reaction was conducted at room temperature with m-chloroperoxybenzoic acid to produce the final products, 1,4-naphthoquinone derivatives EPDMNQ and ENDMNQ. The acidic solution was extracted with dichloromethane $\left(\mathrm{CHCl}_{2} ; 60 \mathrm{ml}\right)$. The organic layer was washed with brine (Fig. 1A and B).

Nuclear magnetic resonance (NMR) spectra were recorded on JNM-AL 600 (600 MHz) and JNM-AL $150(150 \mathrm{MHz})$ spectrometers. Chemical shifts (d) were measured as ppm downfield from tetramethylsilane as the internal standard. Mass spectra were collected with the AB SCIEX API 2000 LC/MS/MS System (Applied Biosystems; Thermo Fisher Scientific, Inc., Waltham, MA, USA) and LCMS-IT-TOF (Shimadzu (China) Co., Ltd., Beijing, China).

Cell lines and cell culture. Human hepatocellular carcinoma cells Hep3B and Huh7, and human hepatoblastoma HepG2 cells were obtained from the American Type Culture Collection (Manassas, VA, USA), and normal liver L-02, normal lung IMR-90 and normal stomach GES-1 cell lines were obtained from (Saiqi Biological Engineering Co., Ltd., 
A<smiles>COc1ccc(OC)c(OC)c1</smiles>

(a) $\mathrm{AlCl}_{3}, \mathrm{NaCl}, 155^{\circ} \mathrm{C}-175^{\circ} \mathrm{C}$;

(b) $\mathrm{MeSO}_{4}, \mathrm{NaOH}, \mathrm{Na}_{2} \mathrm{~S}_{2} \mathrm{O}_{4}, 12 \mathrm{~h}$;

R:

(c) $\mathrm{CAN}$ (cerium ammonium nitrate), rt, $1 \mathrm{~h}, \mathrm{CH}_{3} \mathrm{CN}, \mathrm{CHCl}_{3}$;

(d) $\mathrm{HS}-\mathrm{R}, \mathrm{Na}_{2} \mathrm{Cr}_{2} \mathrm{O}_{7}, \mathrm{H}_{2} \mathrm{SO}_{4}, \mathrm{rt}, 4 \mathrm{~h}, \mathrm{MeOH}$;

(e) MCPBA, rt.

B<smiles>CCCC1(S(=O)(=O)CCC)C(=O)c2c(OC)ccc(OC)c2C1=O</smiles>

\section{2,3-dihydro-2,3-epoxy-2-propylsulfonyl \\ -5,8-dimethoxy-1,4-naphthoquinone (EPDMNQ)}

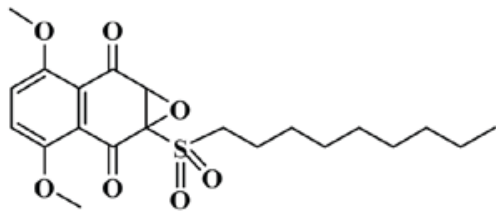

\section{2,3-dihydro-2,3-epoxy-2-nonylsulfonyl \\ -5,8-dimethoxy-1,4-naphthoquinone \\ (ENDMNQ)}

Figure 1. Synthesis of 1,4-naphthoquinone derivatives EPDMNQ and ENDMNQ. (A) Process of synthetic EPDMNQ and ENDMNQ generation. (B) Structural formulas of EPDMNQ and ENDMNQ. EPDMNQ, 2,3-dihydro-2,3-epoxy-2-propylsulfonyl-5,8-dimethoxy-1,4-naphthoquinone; ENDMNQ, 2,3-dihydro-2,3-epoxy-2-nonylsulfonyl-5,8-dimethoxy-1,4-naphthoquinone.

Shanghai, China). Cells were cultured in Dulbecco's modified Eagle's medium (DMEM; Gibco; Thermo Fisher Scientific, Inc., Waltham, MA, USA) supplemented with $10 \%$ fetal bovine serum (Gibco; Thermo Fisher Scientific, Inc.). The cultures were maintained at $37^{\circ} \mathrm{C}$ in a humidified atmosphere of $5 \% \mathrm{CO}_{2}$.

MTT assay. Human hepatocellular carcinoma cells Hep3B and Huh7, human hepatoblastoma HepG2, normal liver L-02, normal lung IMR-90 and normal stomach GES-1 cells were seeded in 96-well plates at a density of $1 \times 10^{4}$ cells/well. Following overnight incubation at $37^{\circ} \mathrm{C}$, cells were treated with different concentrations $(1,3,10,30$ or $100 \mu \mathrm{mol} / \mathrm{l})$ of 5-FU, EPDMNQ and ENDMNQ for $24 \mathrm{~h}$ at $37^{\circ} \mathrm{C}$. Following treatment, $15 \mu \mathrm{l}$ MTT $(5 \mathrm{mg} / \mathrm{ml})$ was added to each well and incubated for $2 \mathrm{~h}$. The absorbance values of the solution were measured at $490 \mathrm{~nm}$ with a microplate illuminometer (BioTek Instruments Inc., Winooski, VT, USA).

Annexin V-fluorescein isothiocyanate (FITC)/propidium iodide (PI) double staining. Hep3B cells were seeded in 6-well plates at a density of $1 \times 10^{6}$ cells/well. After $24 \mathrm{~h}$ incubation at $37^{\circ} \mathrm{C}$, cells were treated with $4 \mu \mathrm{mol} / 15-\mathrm{FU}$, EPDMNQ and ENDMNQ for different time points (0, 3, 6, 12 or $24 \mathrm{~h})$. Cells were washed with PBS, and stained with Annexin V-FITC $(10 \mu \mathrm{l})$ and PI $(5 \mu \mathrm{l})$ in the dark for $15 \mathrm{~min}$. Then, cells were observed using the Leica fluorescence microscope DM 2500 (Leica Microsystems GmbH, Wetzlar, Germany) at magnification, $\mathrm{x} 400$.

Flow cytometry analysis. Hep3B cells were seeded in 6-well plates at a density of $1 \times 10^{6}$ cells/well. After $24 \mathrm{~h}$ incubation at $37^{\circ} \mathrm{C}$, cells were treated with $4 \mu \mathrm{mol} / 1$ 5-FU, EPDMNQ and ENDMNQ for different time points (0, 3, 6, 12 or $24 \mathrm{~h}$ ), and pretreated with $\mathrm{N}$-acetyl cysteine (NAC, $5 \mathrm{mmol} / \mathrm{l}$, Sigma-Aldrich; Merck KGaA) for $30 \mathrm{~min}$ and incubated with $4 \mu \mathrm{mol} / 1$ EPDMNQ and ENDMNQ for $24 \mathrm{~h}$, respectively. Cells were stained with Annexin V-FITC (10 $\mu \mathrm{l})$ and PI $(5 \mu \mathrm{l})$ (Beyotime Institute of Biotechnology, Shanghai, China) in the dark for $15 \mathrm{~min}$. The frequency of apoptotic cells in the treatment groups was determined by flow cytometry (Beckman Coulter, Inc., Brea, CA, USA). Harvested cells were treated with 2',7-dichlorodihydrofluorescein diacetate $(10 \mathrm{mmol} / \mathrm{l})$ (DCFH-DA; Merck, Shanghai, China) at $37^{\circ} \mathrm{C}$ for $30 \mathrm{~min}$ to allow ROS measurement. ROS contents were determined by flow cytometry. Harvested cells were treated with JC-1 (10 $\mu \mathrm{g} / \mathrm{ml}$ ) (Beyotime Institute of Biotechnology) at room temperature for $5 \mathrm{~min}$ to detect mitochondrial membrane potential $(\Delta \Psi \mathrm{m})$ depolarization. States of $\Delta \Psi \mathrm{m}$ depolarization were determined by flow cytometry and CytExpert software (version 1.2; Beckman Coulter, Inc., Brea, CA, USA) was used to analyze the data.

Western blot analysis. Harvested Hep3B cells were lysed in lysis buffer (50 mmol/1 Tris (pH 7.4), $150 \mathrm{mmol} / \mathrm{l} \mathrm{NaCl}$, $1 \%$ Triton $\mathrm{X}-100,1 \%$ sodium deoxycholate, $0.1 \%$ SDS, $20 \mathrm{mg} / \mathrm{ml}$ AEBSF, $0.5 \mathrm{mg} / \mathrm{ml}$ pepstatin, $0.5 \mathrm{mg} / \mathrm{ml}$ leupeptin and $2 \mathrm{mg} / \mathrm{ml}$ aprotinin; Beyotime Institute of Biotechnology), The protein concentrations were determined using Bradford reagent (Bio-Rad Laboratories, Inc., Hercules, CA, USA), following which protein lysates $(30 \mu \mathrm{g})$ were resolved on 8-12\% SDS-PAGE and electrotransferred onto nitrocellulose membranes (EMD Millipore, Billerica, MA, USA). The membranes were blocked for $2 \mathrm{~h}$ at room temperature in fresh 
$5 \%$ non-fat milk in $10 \mathrm{mM}$ Tris- $\mathrm{HCl}$ containing $150 \mathrm{mM} \mathrm{NaCl}$ (TBS; pH 7.5) and TBS+0.2\% Tween-20 (TBST), followed by incubation with specific primary antibodies (all obtained from Santa Cruz Biotechnology, Inc., Dallas, TX, USA) against mouse monoclonal $\alpha$-tubulin (1:2,500; cat. no. sc-8035), Bcl-2 (1:1,500; cat. no. sc-7382), Bax (1:1,500; cat. no. sc-493), cleaved (cle)-poly (adenosine 5-diphosphate-ribose) polymerase (cle-PARP; 1:1,500; cat. no. sc-8007), cle-caspase-3 (1:1,500; cat. no. sc-373730), phosphorylated (p)-p38 $\left(\operatorname{Tyr}^{182}\right.$, 1:1,500; cat. no. sc-7973), p-JNK (Tyr ${ }^{183}$ and $\operatorname{Tyr}^{185}, 1: 1,500$; cat. no. sc-6254), JNK (1:1,500; cat. no. sc-7345), p-ERK (Tyr ${ }^{204}, 1: 1,500$; cat. no. sc-8059), p-STAT3 $\left(\operatorname{Tyr}^{705}, 1: 1,500\right.$; cat. no. sc-8059) and STAT3 (1:1,500; cat. no. sc-8019). Rabbit polyclonal antibodies included p38 $\alpha / \beta(1: 1,500$; cat. no. sc-7972) and ERK2 (1:1,500; cat. no. sc-154), overnight at $4^{\circ} \mathrm{C}$. Following five washes with TBST, the membranes were incubated with peroxidase-conjugated AffiniPure goat anti-mouse IgG (1:5,000; cat. no. ZB-2305; OriGene Technologies, Inc., Beijing, China) and goat anti-rabbit IgG (1:5,000; cat. no. ZB-2305; OriGene Technologies, Inc.) secondary antibodies for $1 \mathrm{~h}$ at room temperature, and immunoreactive protein bands were detected with an Amersham imager (AI600; GE Healthcare, Chicago, IL, USA). The blots were analyzed using Image J version 1.46r (National Institutes of Health, Bethesda, MD, USA) and protein levels were normalized to the matching densitometry value of $\alpha$-tubulin as the internal control. The change of the expression levels of p-p38, p-JNK, p-ERK and p-STAT3 was based on the expression levels of p38, JNK, ERK and STAT3.

Statistical analysis. Data are presented as the mean \pm standard deviation of three independent experiments. The samples of each group were compared by analysis of variance, and multiple comparisons between groups were performed using one-way analysis of variance followed by Tukey's post hoc tests using SPSS version 18.0 statistical software (SPSS, Inc., Chicago, IL, USA). $\mathrm{P}<0.05$ was considered to indicate a statistically significant difference.

\section{Results}

Synthesis of the 1,4-naphthoquinone derivatives EPDMNQ and ENDMNQ. To improve activity and decrease side effects, the chemical synthesis of the 1,4-naphthoquinone derivatives EPDMNQ and ENDMNQ was modified (Fig. 1A and B). By performing NMR at a wavelength of $400 \mathrm{MHz}$, the $\mathrm{H}$ and $\mathrm{C}$ spectra were analyzed in deuterated chloroform solvent and the following structures were identified.

EPDMNQ: ${ }^{1} \mathrm{H}-\mathrm{NMR}\left(\mathrm{CDCl}_{3}, 600 \mathrm{MHz}\right): \delta 7.14$ [singlet (s), $2 \mathrm{H}$ ], 4.5 (s, 1H), 3.99 (s, 6H), 3.60 [multiplet (m), $J=6.5 \mathrm{~Hz}$, 2H], $1.9(\mathrm{~m}, 2 \mathrm{H}), 1.1(\mathrm{~m}, 3 \mathrm{H}) \cdot{ }^{13} \mathrm{C} \mathrm{NMR}\left(\mathrm{CDCl}_{3}, 150 \mathrm{MHz}\right)$ \$187.2 (C-1), 184.6 (C-4), 153.4 (C-5), 152.8 (C-8), 152.7 (C-2), 130.3 (C-3), 128.3 (C-7), 120.7 (C-6), 120.3 (C-10), 120.1 (C-9), $56.8\left(\mathrm{OCH}_{3}\right), 56.4\left(\mathrm{OCH}_{3}\right), 56.9\left(\mathrm{C}-1^{\prime}\right), 49.8\left(\mathrm{C}-2^{\prime}\right), 14.9\left(\mathrm{C}-3^{\prime}\right)$; ion trap-time of flight mass spectrometer (IT-TOF/MS): $\mathrm{m} / \mathrm{z}$ $364.41(\mathrm{M}+\mathrm{Na})+$.

ENDMNQ: ${ }^{1} \mathrm{H}-\mathrm{NMR}\left(\mathrm{CDCl}_{3}, 600 \mathrm{MHz}\right): \delta 7.14(\mathrm{~s}, 2 \mathrm{H})$, 4.5 (s, 1H), 3.99 (s, 6H), 3.60 (m, J=6.4 Hz, 2H), 1.9 (m, 14H), $1.1(\mathrm{~m}, 3 \mathrm{H}) ;{ }^{13} \mathrm{C} \mathrm{NMR}\left(\mathrm{CDCl}_{3}, 150 \mathrm{MHz}\right) . \delta 191.1$ (C-1), 189.3 (C-4), 154.8 (C-5), 153.4 (C-8), 152.8 (C-2), 129.9 (C-3), 128.3
(C-7), 120.7 (C-6), 120.6 (C-10), 119.1 (C-9), $56.8\left(\mathrm{OCH}_{3}\right)$, $56.5\left(\mathrm{OCH}_{3}\right), 56.9\left(\mathrm{C}-1^{\prime}\right), 45.3\left(\mathrm{C}-2^{\prime}\right), 29.7\left(\mathrm{C}-3{ }^{\prime}\right), 25.9\left(\mathrm{C}-4^{\prime}\right)$, 20.5 (C-5'), 15.2 (C-6'), 14.7 (C-6'), 14.7 (C-7'), 14.1 (C-8'), 13.1 (C-9'); IT-TOF/MS: m/z $447.56(\mathrm{M}+\mathrm{Na})+$.

EPDMNQ and ENDMNQ treatment selectively kills liver cancer cells but not normal cells. To determine whether EPDMNQ and ENDMNQ had cytotoxic effects in liver cancer cells, cell viabilities were determined by the MTT assay. As demonstrated in Fig. 2A, EPDMNQ and ENDMNQ inhibited Hep3B, HepG2 and Huh7 cell proliferation in a dose-dependent manner. The cytotoxic effect of EPDMNQ and ENDMNQ on liver cancer cells was significantly greater compared with 5-FU. The effects of EPDMNQ half maximal inhibitory concentration $\left(\mathrm{IC}_{50}\right)$ values of Hep3B, HepG2 and Huh7 cells were $3.89 \pm 1.22,5.26 \pm 1.64$ and $7.68 \pm 1.54 \mu \mathrm{mol} / 1$, respectively. The effects of ENDMNQ $\mathrm{IC}_{50}$ values of Hep3B, HepG2 and Huh7 cells were $4.89 \pm 2.09,6.90 \pm 2.21$ and $16.54 \pm 1.24 \mu \mathrm{mol} / 1$, respectively. As indicated in Fig. 2B, EPDMNQ and ENDMNQ exhibited lower cytotoxicity compared with 5-FU treatment in normal liver L-02, normal lung IMR-90 and normal stomach GES-1 cell lines. As Hep3B cells exhibited the lowest $\mathrm{IC}_{50}$ values, and were most sensitive to EPDMNQ and ENDMNQ of the 3 cancer cell lines, Hep3B cells were used for the subsequent studies

EPDMNQ and ENDMNQ induce apoptosis in Hep3B cells. To determine whether the anti-proliferative effects of EPDMNQ and ENDMNQ were due to effects on cell apoptosis, cell populations were detected by fluorescence microscopy. As demonstrated in Fig. 3A and B, the fluorescence intensities of Annexin V-FITC and PI were increased in a time-dependent manner. Early and late apoptotic cells were detected by flow cytometry, and identified that the percentage of apoptotic cells after $24 \mathrm{~h}$ of EPDMNQ and ENDMNQ treatment were 59.03 and $47.39 \%$, respectively (Fig. 3C and D). EPDMNQ and ENDMNQ treatment groups exhibited a significant increase $(\mathrm{P}<0.001)$ cell apoptosis compared with the $5-\mathrm{FU}$ groups. These results suggested that the anti-cancer effects of EPDMNQ and ENDMNQ were also associated with the induction of cell apoptosis.

EPDMNQ and ENDMNQ induce apoptosis by modulating the mitochondrial, MAPK and STAT3 signaling pathways in Hep3B cells. To determine the molecular mechanisms of apoptosis induced by EPDMNQ and ENDMNQ, the expression levels of proteins were assessed by western blot analysis. As indicated in Fig. 4A and B, the expression levels of Bax, cle-PARP and cle-caspase-3 were increased and that of Bcl-2 was decreased in a time-dependent manner, with maximum changes occurring at $24 \mathrm{~h}$. As demonstrated in Fig. 4C and D, EPDMNQ and ENDMNQ significantly increased the phosphorylation levels of p38 and JNK, whereas the phosphorylation levels of ERK and STAT3 were decreased in a time-dependent manner. These data demonstrated that EPDMNQ and ENDMNQ induced cell apoptosis through the mitochondrial, MAPK, and STAT3 signaling pathways.

Accumulation of ROS induced by EPDMNQ and ENDMNQ participates in the apoptosis of Hep3B cells. To determine 
A

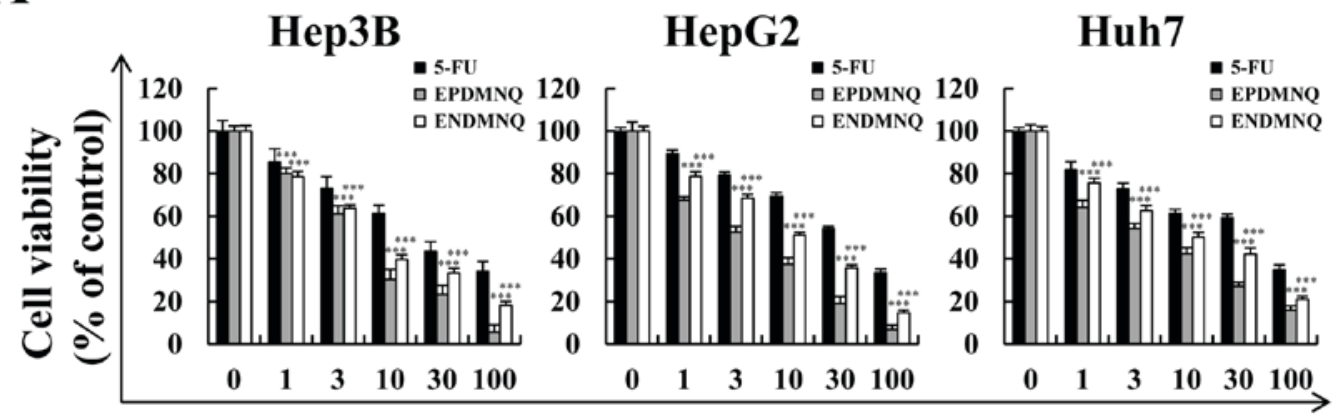

B

Concentration $(\mu \mathrm{M})$

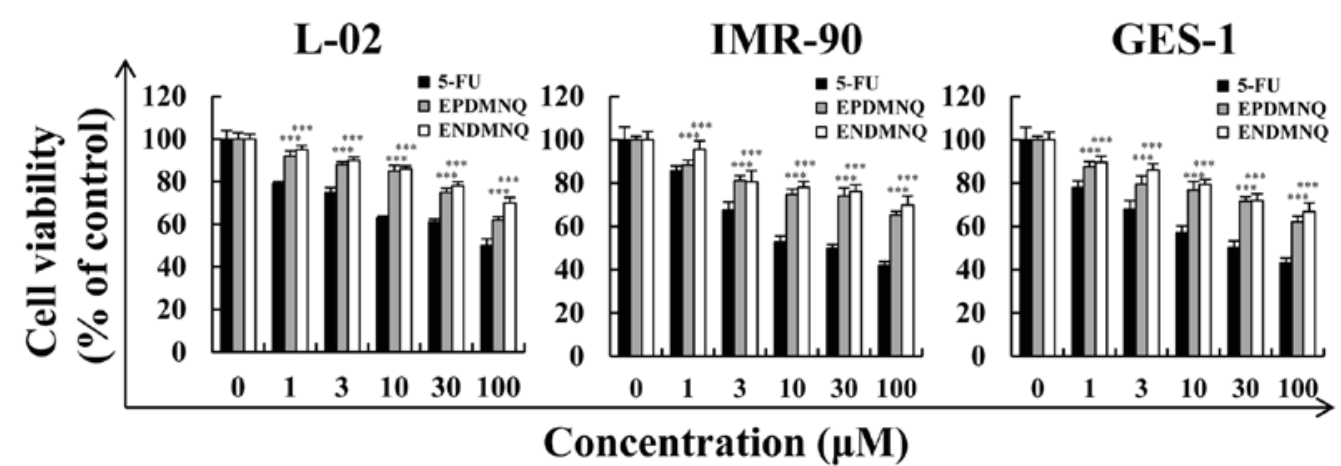

Figure 2. Effects of EPDMNQ and ENDMNQ on the viabilities of liver cancer and normal cells. (A) Hep3B, HepG2 and Huh7 cells were treated with different concentrations $(1,3,10,30$ or $100 \mu \mathrm{mol} / \mathrm{l})$ of 5-FU, EPDMNQ or ENDMNQ for $24 \mathrm{~h}$. Cell viability was determined by MTT assay. (B) Normal liver L-02, normal lung IMR-90 and normal stomach GES-1 cell line viabilities. Data are expressed as the percentage of viable cells. ${ }^{* * *} \mathrm{P}<0.001$ vs. 5-FU group. EPDMNQ, 2,3-dihydro-2,3-epoxy-2-propylsulfonyl-5,8-dimethoxy-1,4-naphthoquinone; ENDMNQ, 2,3-dihydro-2,3-epoxy-2-nonylsulfonyl-5,8-dimethoxy-1,4-naphthoquinone; 5-FU, 5-fluorouracil.

whether EPDMNQ and ENDMNQ-induced apoptosis was associated with intracellular ROS generation in Hep3B cells, the association between intracellular ROS levels and apoptosis was evaluated by flow cytometry. As presented in Fig. 5A and B, Hep3B cells treated with EPDMNQ and ENDMNQ exhibited increased levels of ROS in a time-dependent manner. $\Delta \Psi \mathrm{m}$ depolarization was measured by $\mathrm{JC}-1$, as the processing time was extended from 0 to $24 \mathrm{~h}$. The green fluorescence intensity was continuously enhanced, indicating that apoptosis gradually increased in Hep3B cells in a time-dependent manner. Treatment with the ROS inhibitor $N$-acetyl-L-cysteine (NAC) reversed the degree of apoptosis induced by EPDMNQ and ENDMNQ (Fig. 5E and F). It was also identified that the treatment of Hep3B cells with NAC reversed the expression levels of proteins regulated by EPDMNQ and ENDMNQ in the mitochondrial, MAPK, and STAT3 signaling pathways, namely JNK, ERK, STAT3, Bcl-2, Bax, cle-PARP and cle-caspase-3 (Fig. 6A and B). These data demonstrated that ROS generation was the key regulator of EPDMNQ and ENDMNQ-induced apoptosis.

\section{Discussion}

The compound 1,4-naphthoquinone is a type of organic molecule derived from naphthalene; naphthoquinone derivatives have a number of pharmacological effects including anti-viral, anti-bacterial and anti-inflammatory activities (31). At present, studies on naphthoquinone derivatives have primarily focused on 5,8-dihydroxy-1,4-naphthoquinone and substitutions at the $\mathrm{C} 2$ and $\mathrm{C} 6$ positions of 5-dimethoxy-1,4-naphthoquinone, but rarely on 1,4-naphthoquinone $(32,33)$. Although 1,4-naphthoquinone may inhibit the growth of a variety of cancer cells, the majority of 1,4-naphthoquinone derivatives exhibit high cytotoxicity and side effects, so they are not suitable for clinical treatment (34). Therefore, a number of attempts have been made to identify novel therapeutic compounds that are efficacious but have fewer side effects.

In the present study, 2 types of novel 1,4-naphthoquinone derivatives (ENDMNQ and EPDMNQ) were synthesized and their anti-proliferation effects were screened in liver cancer Hep3B, HepG2 and Huh7 cell lines. The liver cancer cells commonly used in drug screening experiments include HepG2, Hep3B, Huh7, SMMC7721, Bel-7402, MHCC97 and PLC/PRF/5 (35-38). HepG2 cells are human hepatoblastoma that were isolated and established from a primary hepatic blastoma of a 15-year-old Caucasian boy in Argentina in 1979 (39). Hep3B cells are human hepatoma cell line isolated from a liver cancer tissue of an 8-year-old African male (40). Huh7 cells are human hepatoma cell line obtained from a 57-year-old Japanese male liver cancer tissue specimen in 1982 (41). These 3 cell lines have a high degree of differentiation; the metabolism remains stable and will not change due to the increased number of passages and in drug screening studies. Therefore, the present study used Hep3B, HepG2 and Huh7 cells. Compared with 5-FU treatment, 
A
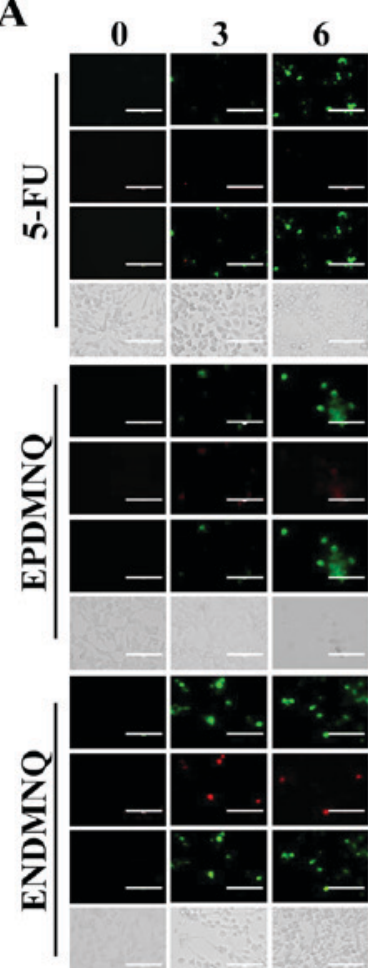

C

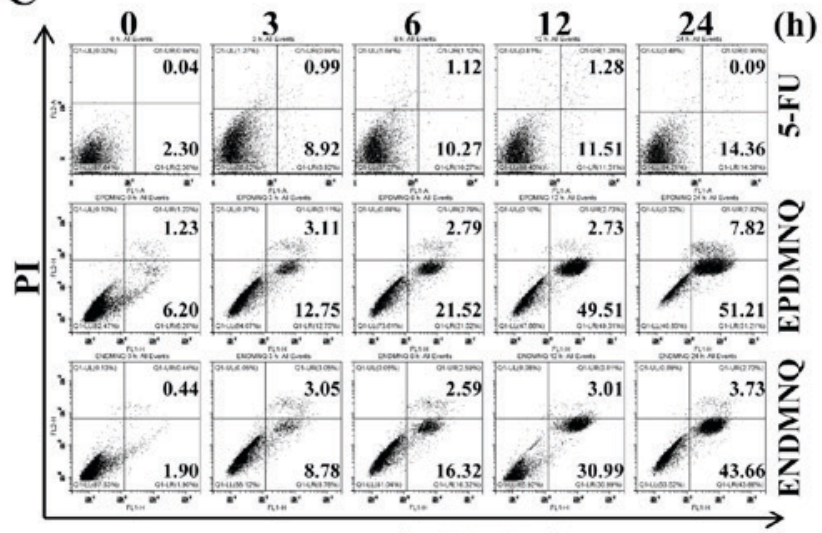

Annexin V-FITC
B

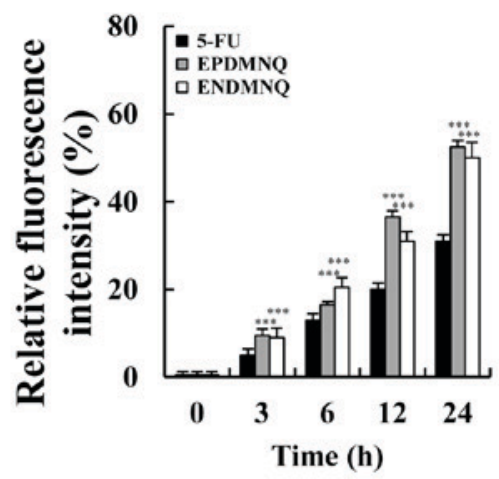

D

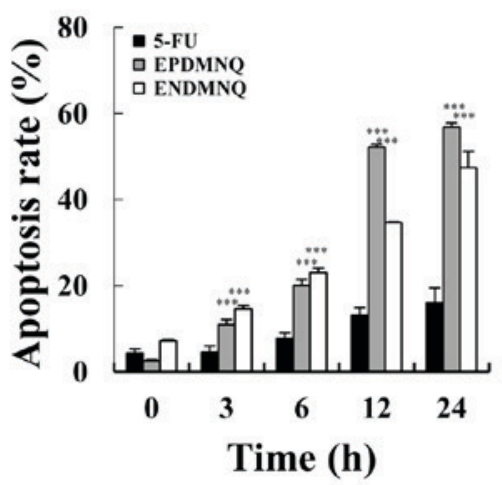

Figure 3. EPDMNQ and ENDMNQ induce apoptosis in hepatocellular carcinoma cells. (A) Hep3B cells were treated with $4 \mu$ mol/1 5-FU, EPDMNQ or ENDMNQ for different time intervals (3, 6, 12 or 24 h) and stained with Annexin V-FITC/PI. Images represent fluorescence microscopic images (original magnifications, x400). (B) Quantification of fluorescence intensities from A. (C) Apoptosis distribution was determined by flow cytometry following treatment with $4 \mu \mathrm{mol} / 1$ 5-FU, EPDMNQ or ENDMNQ for different time intervals (3, 6, 12 or $24 \mathrm{~h})$. (D) Quantification of flow cytometry from C. Data are expressed as the percentage of viable cells. ${ }^{* * *} \mathrm{P}<0.001$ vs. 5-FU group. EPDMNQ, 2,3-dihydro-2,3-epoxy-2-propylsulfonyl-5,8-dimethoxy-1,4-naphthoquinone; ENDMNQ, 2,3-dihydro-2,3-epoxy-2-nonylsulfonyl-5,8-dimethoxy-1,4-naphthoquinone; 5-FU, 5-fluorouracil; FITC, fluorescein isothiocyanate; PI, propidium iodide.

the cytotoxic effects of EPDMNQ and ENDMNQ were more potent in Hep3B cells compared with HepG2 and Huh7 cells. Certain doses $(1,3,10,30$ or $100 \mu \mathrm{mol} / \mathrm{l})$ of EPDMNQ and ENDMNQ effectively induced liver cancer cell apoptosis but exhibited less harmful effects in normal liver L-02, normal lung IMR-90 and normal stomach GES-1 cell lines. It was also identified that the $\mathrm{IC}_{50}$ of EPDMNQ was decreased compared with $\mathrm{IC}_{50}$ of ENDMNQ. As the substituent chains of EPDMNQ and ENDMNQ are different in length, the cytotoxic effects of the 2 compounds on liver cancer cells are significantly different. The cytotoxic effect of EPDMNQ with longer carbon chains on liver cancer cells is more marked compared with that of ENDMNQ.
Apoptosis is a common way of removing aged cells from the body that serves an essential role in organism development and tissue homeostasis. The majority of anti-cancer therapies trigger apoptosis induction and regulate signaling pathways to eliminate cancer cells (42). As a canonical pathway that allows cells to undergo a highly regulated form of cell death in response to pro-apoptotic stimuli, apoptosis is triggered by multiple signaling pathways (43). The mitochondrion serves an important role in the integration and transmission of signals to induce apoptotic cell death and is regulated by pro-apoptotic Bax and anti-apoptotic Bcl-2 proteins. Caspase-3 is a critical executioner of apoptosis and acts by cleaving several essential 
A
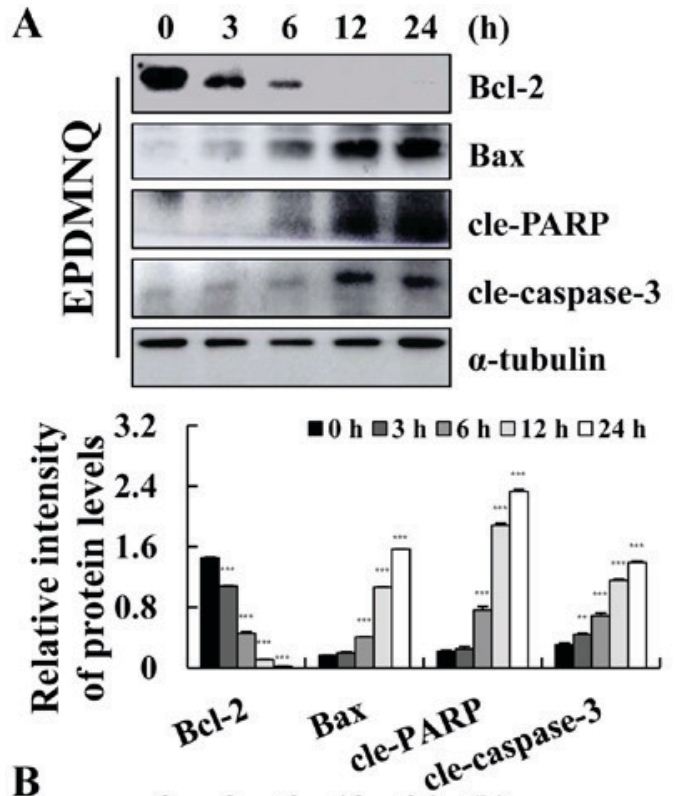

B
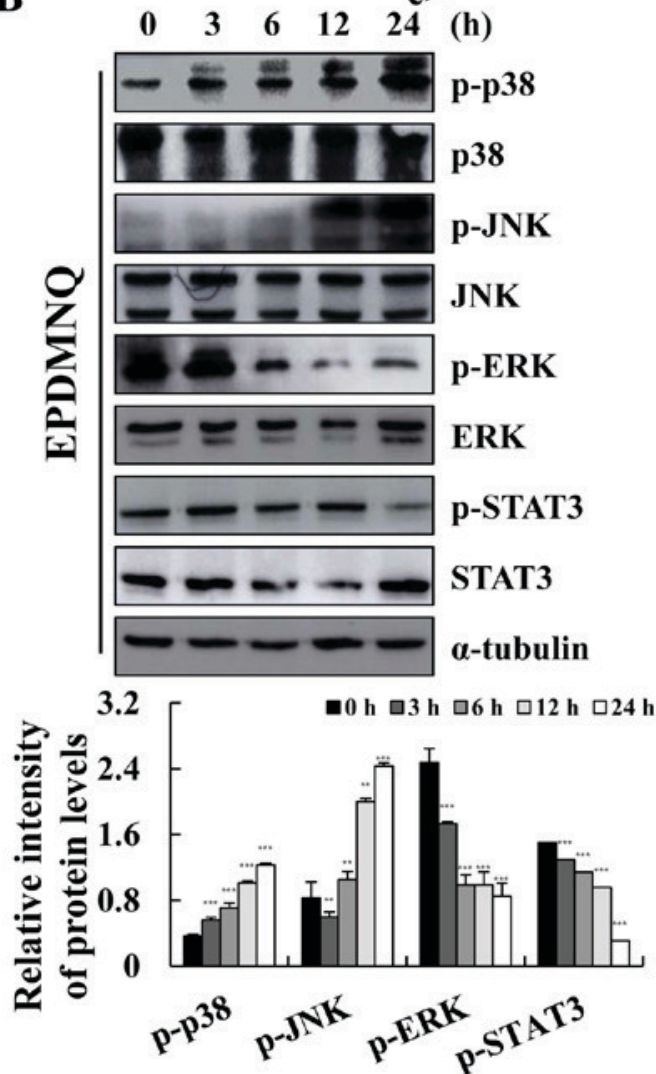
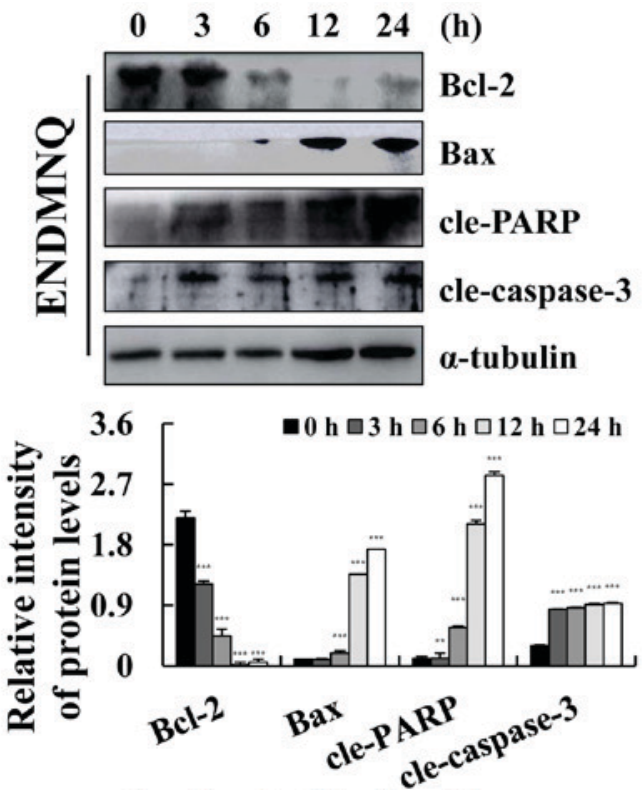

$\begin{array}{lllllll}0 & 3 & 6 & 12 & 24 & \text { (h) }\end{array}$
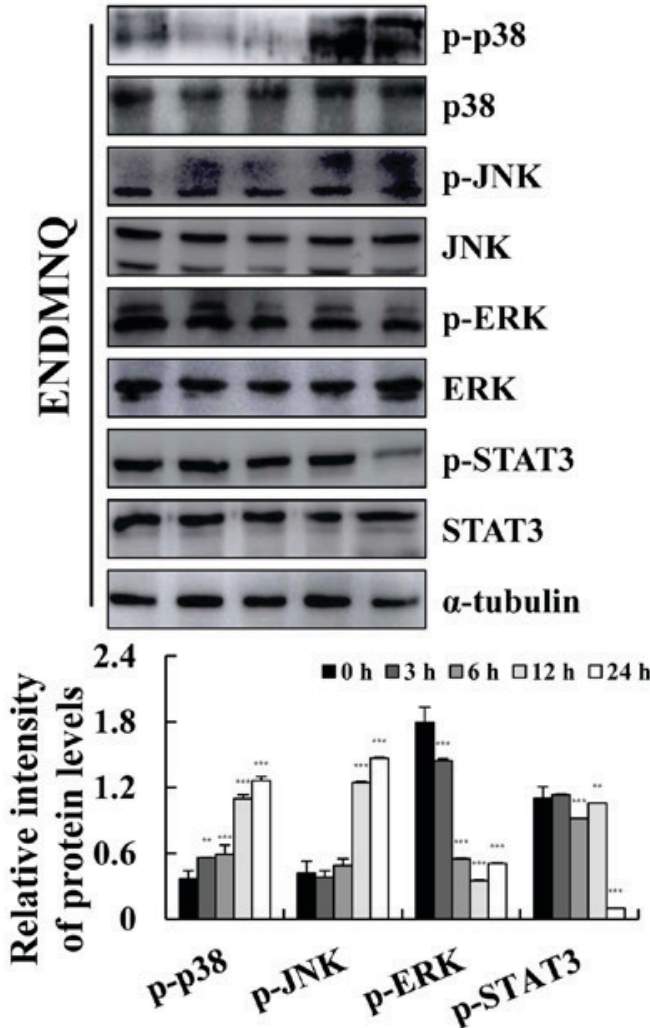

Figure 4. EPDMNQ and ENDMNQ regulate mitochondrial, MAPK and STAT3 signaling pathways-associated proteins in Hep3B cells. (A) Hep3B cells were treated with EPDMNQ or ENDMNQ for different time intervals $(3,6,12$ or $24 \mathrm{~h})$. The expression levels of mitochondrial pathway-associated proteins were analyzed by western blot analysis. (B) The expression levels of MAPK and STAT3 pathway-associated proteins were analyzed by western blot analysis. $\alpha$-tubulin was used as the internal control. Band intensity was quantified using the Image $\mathrm{J}$ software. ${ }^{* *} \mathrm{P}<0.01$ and ${ }^{* * * *} \mathrm{P}<0.001$ vs. untreated control group. EPDMNQ, 2,3-dihydro-2,3-epoxy-2-propylsulfonyl-5,8-dimethoxy-1,4-naphthoquinone; ENDMNQ, 2,3-dihydro-2,3-epoxy-2-nonylsulfonyl-5,8-dimethoxy-1,4-naphthoquinone; Bcl-2, B-cell lymphoma 2; Bax, Bcl-2-associated X protein; cle, cleaved; PARP, poly (adenosine 5-diphosphate-ribose) polymerase; p, phosphorylated; p38, p38 mitogen-activated protein kinase; JNK, c-Jun N-terminal kinase; ERK, extracellular signal regulated kinase; STAT3, signal transducer and activator of transcription 3.

cellular proteins, including PARP (44). The results of the present study indicated that EPDMNQ and ENDMNQ treatment induced a significant change in cell morphology. Annexin V-FITC/PI double staining and flow cytometry demonstrated that Hep3B cells treated with EPDMNQ and ENDMNQ induced apoptosis in a dose-dependent manner. Concomitantly, it was identified that EPDMNQ treatment exhibited a more marked induction of apoptosis compared with ENDMNQ. Furthermore, Hep3B cell apoptosis was regulated by increased protein levels of Bax, cle-PARP and cle-caspase- 3 and decreased levels of Bcl-2. We hypothesized that the EPDMNQ and ENDMNQ treatment of Hep3B cells induced apoptosis 
A

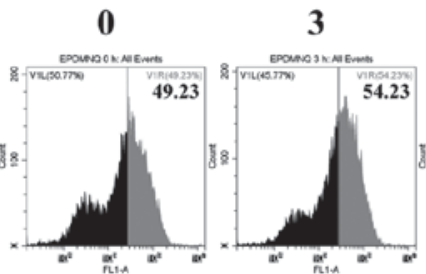

B
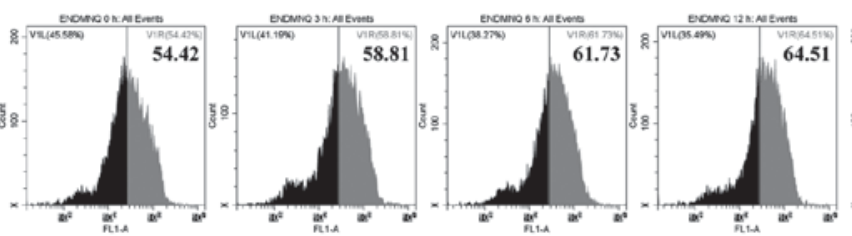

C

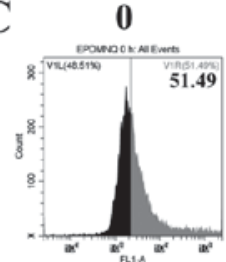
3
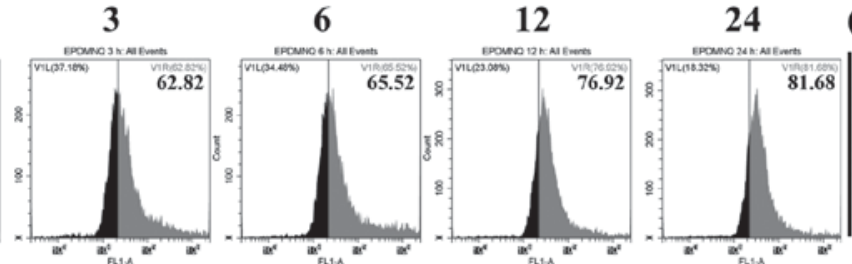

D

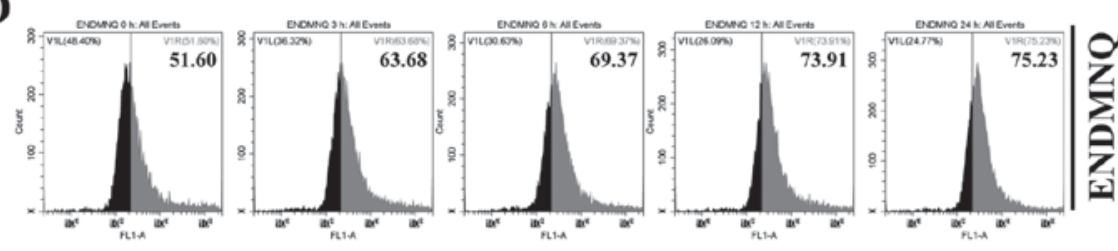

(h)

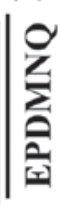

(h)

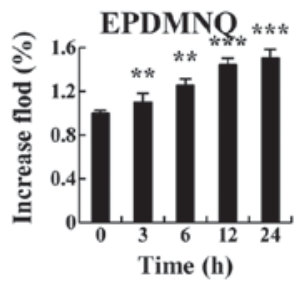

ENDMNQ

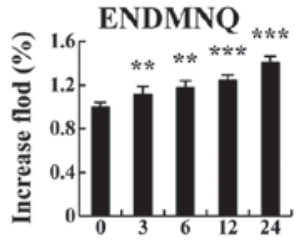

Time (h)

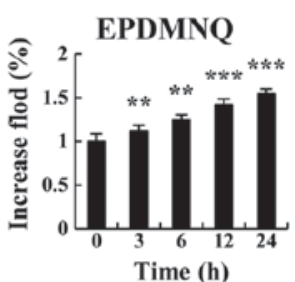

Time (h)

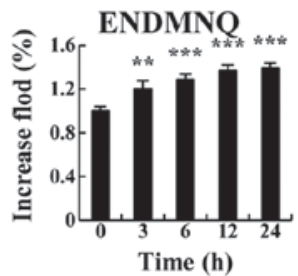

$\mathbf{E}$
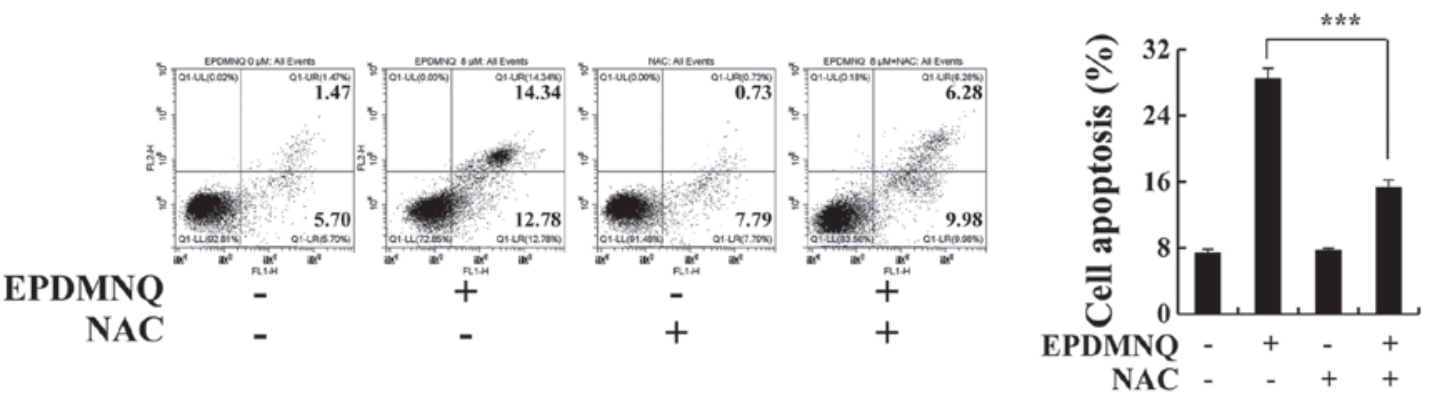

F
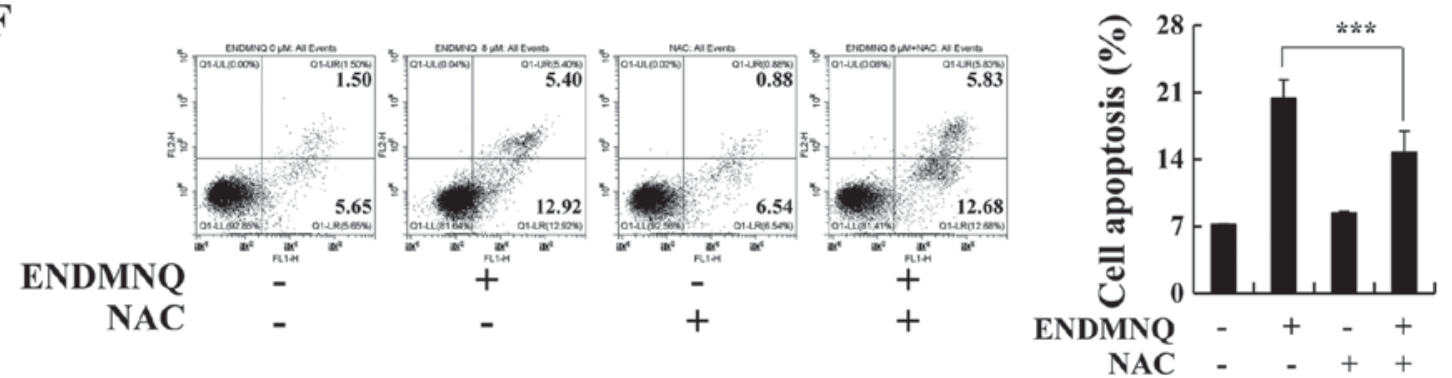

Figure 5. EPDMNQ and ENDMNQ-induced apoptosis is restored by ROS inhibition in Hep3B cells. (A and B) Intracellular ROS generation induced by EPDMNQ or ENDMNQ was measured in Hep3B cells following staining with 2',7'-dichlorodihydrofluorescein diacetate and detected by flow cytometry. (C and D) Hep3B cells were treated with EPDMNQ or ENDMNQ for $24 \mathrm{~h}$, and mitochondrial membrane potential depolarization value was detected by flow cytometry following JC-1 staining. (E) Hep3B cells were treated with NAC for 30 min and then incubated with EPDMNQ for 24 h. Cell apoptosis was determined by flow cytometry. (F) Apoptotic cell numbers were detected following ENDMNQ treatment by flow cytometry. Data are expressed as the apoptotic cell numbers. ${ }^{* *} \mathrm{P}<0.01$ and ${ }^{* * *} \mathrm{P}<0.001$ vs. untreated control group. EPDMNQ, 2,3-dihydro-2,3-epoxy-2-propylsulfonyl-5,8-dimethoxy-1,4-naphthoquinone; ENDMNQ, 2,3-dihydro-2,3-epoxy-2-nonylsulfonyl-5,8-dimethoxy-1,4-naphthoquinone; ROS, reactive oxygen species; NAC, $N$-acetyl-L-cysteine.

via a mitochondrial-dependent pathway. MAPK is a critical signaling pathway that serves a role in cancer cell survival, dissemination and resistance to drug therapy (45-47). STAT3 regulates a number of cardinal features of cancer, including cancer cell growth and resistance to apoptosis, and has been validated as a drug target for cancer therapy (48). Following 
A

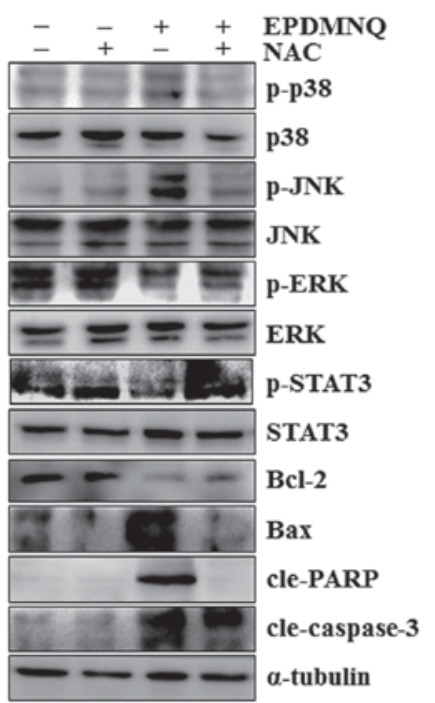

B

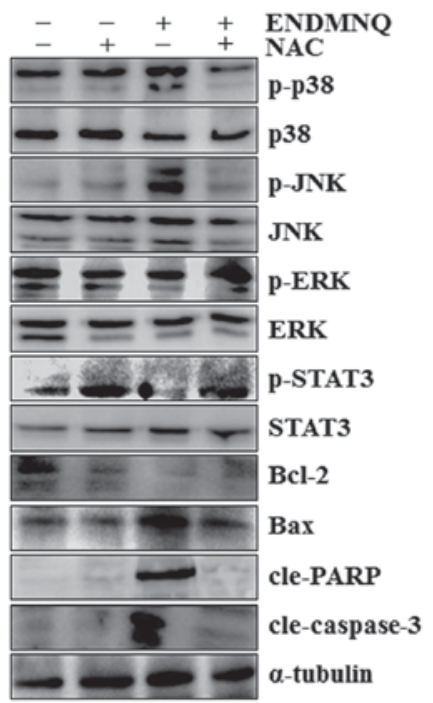

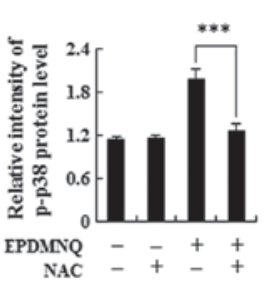
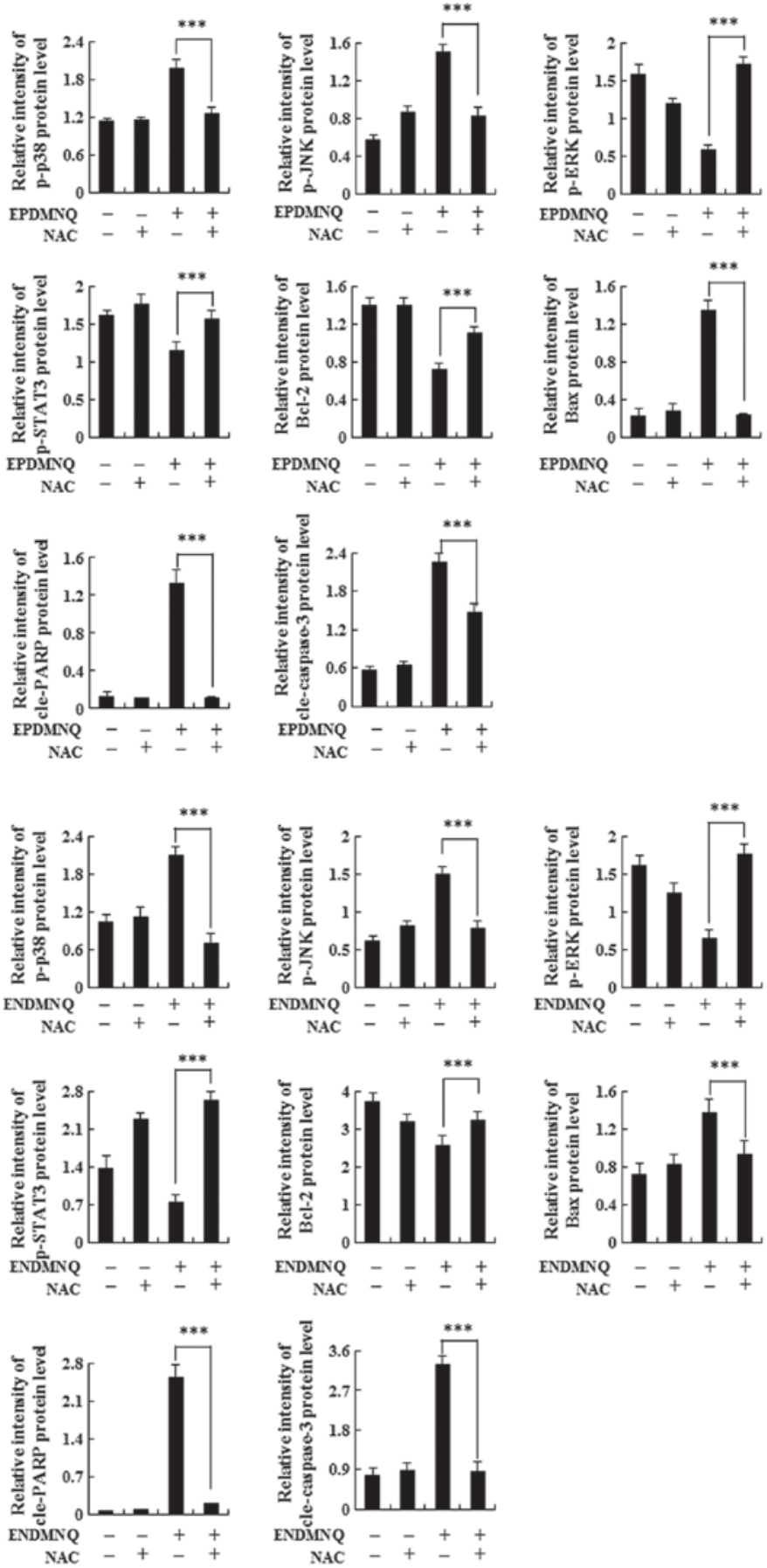

EPDMNQ $-\overline{+}+$
NAC -+

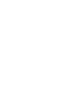

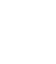


apoptosis was accompanied by ROS accumulation, which was reversed by pretreatment with the ROS inhibitor NAC. In the present study, EPDMNQ- and ENDMNQ-induced apoptosis was accompanied by ROS accumulation and mitochondrial membrane potential depolarization, which was reversed by pretreatment with the ROS inhibitor NAC in a time-dependent manner. The expression levels of the pro-apoptotic protein Bax, cle-PARP and cle-caspase- 3 and the anti-apoptotic protein Bcl-2 were also examined by western blot analysis. EPDMNQ and ENDMNQ treatment significantly increased the levels of Bax, cle-PARP and cle-caspase-3 and decreased Bcl-2 protein levels; these effects were reversed upon NAC pretreatment. In addition, EPDMNQ and ENDMNQ significantly promoted the phosphorylation of JNK and p38 but inhibited that of ERK; these effects were also reversed with NAC pretreatment. These results demonstrated that EPDMNQ and ENDMNQ induced ROS-mediated apoptosis via the MAPK and STAT3 signaling pathways. The effects of EPDMNQ and ENDMNQ demonstrated in vivo should be evaluated in future studies. EPDMNQ and ENDMNQ-induced apoptosis are in addition to the changes in intracellular ROS levels already mentioned in the present study, including many other causes, including cell autophagy, endoplasmic reticulum stress and DNA damage. The experimental results of the present study do not fully explain the causes of apoptosis caused by EPDMNQ and ENDMNQ. Therefore, the other potential mechanisms of apoptosis, with the exception of ROS, induced by EPDMNQ and ENDMNQ will be examined in future studies.

Taken together, the results of the present study demonstrated that 2 novel types of 1,4-naphthoquinone derivatives, EPDMNQ and ENDMNQ, induced apoptosis through ROS modulation of the MAPK and STAT3 signaling pathways in Hep3B cells. Therefore, EPDMNQ and ENDMNQ may be potential chemotherapeutic agents for the treatment of HCC.

\section{Acknowledgements}

Not applicable.

\section{Funding}

The present study was funded by the Multigrain Production and Processing Characteristic Discipline Construction Project, the Postdoctoral Scientific Research Foundation of Heilongjiang Province of China (grant no. LBH-Q13132) and the Scientific Research Foundation of Heilongjiang Provincial Education Department of China (grant no. 1252HQ007).

\section{Availability of data and materials}

The datasets used or analysed during the current study are available from the corresponding author on reasonable request.

\section{Authors' contributions}

CHJ and DJZ conceived and designed the study. YW, YHL, XJP, GNS, LQM, YZ, JRW, JQL, HW, WTX, YL, YZ, YHH; MHJ and YQZ performed the experiments. TZ, SNW and HNS analyzed the data. YW and YHL wrote the manuscript. All authors read and approved the final manuscript.

\section{Ethics approval and consent to participate}

Not applicable.

\section{Patient consent for publication}

Not applicable.

\section{Competing interests}

The authors declare that they have no competing interests.

\section{References}

1. Zhang ZQ, Meng H, Wang N, Liang LN, Liu LN, Lu SM and Luan Y: Serum microRNA 143 and microRNA 215 as potential biomarkers for the diagnosis of chronic hepatitis and hepatocellular carcinoma. Diagn Pathol 9: 135, 2014.

2. Sellam F, Harir N, Khaled MB, Mrabent NM, Salah R, Benchouk A and Diaf M: Delayed diagnosis of pancreatic cancer reported as more common in a population of North African young adults. J Gastrointest Oncol 6: 505-510, 2015.

3. Bruix J, Reig M and Sherman M: Evidence-based diagnosis, staging, and treatment of patients with hepatocellular carcinoma. Gastroenterology 150: 835-853, 2016.

4. LiQ,Zhu LZ, Yang RJ and Zhu X: Cytotoxic activity of anticancer drugs on hepatocellular carcinoma cells in hypoxic-hyponutritional culture. Int Surg 99: 745-752, 2014.

5. Loureiro R, Magalhães-Novais S, Mesquita KA, Baldeiras I, Sousa IS, Tavares LC, Barbosa IA, Oliveira PJ and Vega-Naredo I: Melatonin antiproliferative effects require active mitochondrial function in embryonal carcinoma cells. Oncotarget 6: 17081-17096, 2015.

6. Wang X, Yan Y, Yang L, Li M and Zhong X: Effect of quercetin on the expression of Bcl-2/Bax apoptotic proteins in endometrial cells of lipopolysaccharide-induced-abortion mice. J Tradit Chin Med 36: 737-742, 2016.

7. Yang SY, Miah A, Sales KM, Fuller B, Seifalian AM and Winslet M: Inhibition of the p38 MAPK pathway sensitises human colon cancer cells to 5-fluorouracil treatment. Int J Oncol 38: 1695-1702, 2011.

8. Bao H, Guo CG, Qiu PC, Zhang XL, Dong Q and Wang YK: Long non-coding RNA Igf2as controls hepatocellular carcinoma progression through the ERK/MAPK signaling pathway. Oncol Lett 14: 2831-2837, 2017.

9. Lu X, Li C, Wang YK, Jiang K and Gai XD: Sorbitol induces apoptosis of human colorectal cancer cells via p38 MAPK signal transduction. Oncol Lett 7: 1992-1996, 2014.

10. Giachello CN, Fiumara F, Giacomini C, Corradi A, Milanese C, Ghirardi M, Benfenati $\mathrm{F}$ and Montarolo PG: MAPK/Erk-dependent phosphorylation of synapsin mediates formation of functional synapses and short-term homosynaptic plasticity. J Cell Sci 123: 881-893, 2010.

11. Pereira L, Igea A, Canovas B, Dolado I and Nebreda AR: Inhibition of p38 MAPK sensitizes tumour cells to cisplatin-induced apoptosis mediated by reactive oxygen species and JNK. EMBO Mol Med 5: 1759-1774, 2013.

12. Qu J, Zhao M, Teng Y, Zhang Y, Hou K, Jiang Y, Yang X, Shang H, Qu X and Liu Y: Interferon- $\alpha$ sensitizes human gastric cancer cells to TRAIL-induced apoptosis via activation of the c-CBL-dependent MAPK/ERK pathway. Cancer Biol Ther 12: 494-502, 2011.

13. Atay $\mathrm{O}$ and Skotheim JM: Spatial and temporal signal processing and decision making by MAPK pathways. J Cell Biol 216: 317-330, 2017.

14. Gong J, Lv L and Huo J: Roles of F-box proteins in human digestive system tumors (Review). Int J Oncol 45: 2199-2207, 2014.

15. Tasaki S, Horiguchi A, Asano T, Ito K, Asano T and Asakura H: Docosahexaenoic acid inhibits the phosphorylation of STAT3 and the growth and invasion of renal cancer cells. Exp Ther Med 14: 1146-1152, 2017.

16. Yuan J, Zhang F and Niu R: Multiple regulation pathways and pivotal biological functions of STAT3 in cancer. Sci Rep 5: 17663, 2015. 
17. Bharadwaj U, Eckols TK, Kolosov M, Kasembeli MM, Adam A, Torres D, Zhang X, Dobrolecki LE, Wei W, Lewis MT, et al: Drug-repositioning screening identified piperlongumine as a direct STAT3 inhibitor with potent activity against breast cancer. Oncogene 34: 1341-1353, 2015.

18. Kron KJ, Murison A, Zhou S, Huang V, Yamaguchi TN, Shiah YJ, Fraser M, van der Kwast T, Boutros PC, Bristow RG, et al TMPRSS2-ERG fusion co-opts master transcription factors and activates NOTCH signaling in primary prostate cancer. Nat Genet 49: 1336-1345, 2017.

19. Lai ZQ, Ip SP, Liao HJ, Lu Z, Xie JH, Su ZR, Chen YL, Xian YF, Leung PS and Lin ZX: Brucein D, a naturally occurring tetracyclic triterpene quassinoid, induces apoptosis in pancreatic cancer through ROS-associated PI3K/Akt signaling pathway. Front Pharmacol 8: 936, 2017.

20. Sengupta D, Mazumdar ZH, Mukherjee A, Sharma D, Halder AK, Basu S and Jha T: Benzamide porphyrins with directly conjugated and distal pyridyl or pyridinium groups substituted to the porphyrin macrocycles: Study of the photosensitising abilities as inducers of apoptosis in cancer cells under photodynamic conditions. J Photochem Photobiol B 178: 228-236, 2017.

21. Sun J, Song B, Ye Z and Yuan J: Mitochondria targetable time-gated luminescence probe for singlet oxygen based on a $\beta$-diketonate-europium complex. Inorg Chem 54: 11660-11668, 2015.

22. Gonzalez AA, Zamora L, Reyes-Martinez C, Salinas-Parra N Roldan N, Cuevas CA, Figueroa S, Gonzalez-Vergara A and Prieto MC: (Pro)renin receptor activation increases profibrotic markers and fibroblast-like phenotype through MAPK-dependent ROS formation in mouse renal collecting duct cells. Clin Exp Pharmacol Physiol 44: 1134-1144, 2017.

23. Liu XM, Peyton KJ and Durante W: Ammonia promotes endothelial cell survival via the heme oxygenase-1-mediated release of carbon monoxide. Free Radic Biol Med 102: 37-46, 2017.

24. Guerriero E, Sorice A, Capone F, Napolitano V, Colonna G, Storti G, Castello G and Costantini S: Vitamin C effect on mitoxantrone-induced cytotoxicity in human breast cancer cell lines. PLoS One 9: e115287, 2014.

25. Coelho-Cerqueira E1, Netz PA, do Canto VP, Pinto AC and Follmer C: Beyond topoisomerase inhibition: Antitumor 1,4-naphthoquinones as potential inhibitors of human monoamine oxidase. Chem Biol Drug Des 83: 401-410, 2014

26. Graciani FS and Ximenes VF: 2-Bromo-1,4-naphthoquinone: A potentially improved substitute of menadione in Apatone ${ }^{\mathrm{TM}}$ therapy. Braz J Med Biol Res 45: 701-710, 2012.

27. Ju Woo H, Jun DY, Lee JY, Park HS, Woo MH, Park SJ, Kim SC, Yang $\mathrm{CH}$ and Kim YH: Anti-inflammatory action of 2-carbomethoxy-2,3-epoxy-3-prenyl-1,4-naphthoquinone (CMEP-NQ) suppresses both the MyD88-dependent and TRIF-dependent pathways of TLR4 signaling in LPS-stimulated RAW264.7 cells. J Ethnopharmacol 205: 103-115, 2017.

28. P R KR, Fernandez A, Laila SP, B A, C S S and V S V: Synthesis, spectral characterization, crystal structure, cytotoxicity and apoptosis-Inducing activity of two derivatives of 2-hydroxy-1,4-naphthaquinone. Photodiagnosis Photodyn Ther 17: 250-259, 2017.

29. Kawiak A and Lojkowska E: Ramentaceone, a naphthoquinone derived from drosera sp., induces apoptosis by suppressing PI3K/Akt signaling in breast cancer cells. PLoS One 11: e0147718, 2016.

30. Liu C, Shen GN, Luo YH, Piao XJ, Jiang XY, Meng LQ, Wang Y, Zhang Y, Wang JR, Wang H, et al: Novel 1,4-naphthoquinone derivatives induce apoptosis via ROS-mediated p38/MAPK, Akt and STAT3 signaling in human hepatoma Hep3B cells. Int J Biochem Cell Biol 96: 9-19, 2018.

31. P1rachayasittikul V, Pivngaew R, Worachartcheewan A, Nantasenamat C, Prachayasittikul S, Ruchirawat S and Prachayasittikul V: Synthesis, anticancer activity and QSAR study of 1,4-naphthoquinone derivatives. Eur J Med Chem 84: 247-263, 2014

32. Lee JJ, Zhang WY, Yi H, Kim Y, Kim IS, Shen GN, Song GY and Myung CS: Anti-proliferative actions of 2-decylamino-5,8-dimethoxy-1,4-naphthoquinone in vascular smooth muscle cells. Biochem Biophys Res Commun 411: 213-218, 2011.

33. Lara LS, Moreira CS, Calvet CM, Lechuga GC, Souza RS, Bourguignon SC, Ferreira VF, Rocha D and Pereira MCS: Efficacy of 2-hydroxy-3-phenylsulfanylmethyl-[1,4]-naphthoquinone derivatives against different Trypanosoma cruzi discrete type units: Identification of a promising hit compound. Eur J Med Chem 144: 572-581, 2017.
34. Kishore N, Binneman B, Mahapatra A, van de Venter M, du Plessis-Stoman D, Boukes G, Houghton P, Marion Meyer JJ and Lall N: Cytotoxicity of synthesized 1,4-naphthoquinone analogues on selected human cancer cell lines. Bioorg Med Chem 22: 5013-5019, 2014.

35. Bahman AA, Abaza MSI, Khoushiash SI and Al-Attiyah RJ: Sequence-dependent effect of sorafenib in combination with natural phenolic compounds on hepatic cancer cells and the possible mechanism of action. Int J Mol Med 42: 1695-1715, 2018.

36. You ML, Chen YJ, Chong QY, Wu MM, Pandey V, Chen RM, Liu L, Ma L, Wu ZS, Zhu T and Lobie PE: Trefoil factor 3 mediation of oncogenicity and chemoresistance in hepatocellular carcinoma is AKT-BCL-2 dependent. Oncotarget 8: 39323-39344, 2017.

37. Zhang Y, Li H, Chang H, Du L, Hai J, Geng X and Yan X: MTP18 overexpression contributes to tumor growth and metastasis and associates with poor survival in hepatocellular carcinoma. Cell Death Dis 9: 956, 2018.

38. Guamán-Ortiz LM, Orellana MI and Ratovitski EA: Natural compounds as modulators of non-apoptotic cell death in cancer cells. Curr Genomics 18: 132-155, 2017.

39. Aden DP, Fogel A, Plotkin S, Damjanov I and Knowles BB: Controlled synthesis of HBsAg in a differentiated human liver carcinoma-derived cell line. Nature 282: 615-616, 1979.

40. Morris KM, Aden DP, Knowles BB and Colten HR: Complement biosynthesis by the human hepatoma-derived cell line HepG2. J Clin Invest 70: 906-913, 1982.

41. Nakabayashi H, Taketa K, Miyano K, Yamane T and Sato J: Growth of human hepatoma cells lines with differentiated functions in chemically defined medium. Cancer Res 42: 3858-3863, 1982.

42. Mohammad RM, Muqbil I, Lowe L, Yedjou C, Hsu HY, Lin LT, Siegelin MD, Fimognari C, Kumar NB, Dou QP, et al: Broad targeting of resistance to apoptosis in cancer. Semin Cancer Biol 35 (Suppl): S78-S103, 2015.

43. Panganiban RA, Snow AL and Day RM: Mechanisms of radiation toxicity in transformed and non-transformed cells. Int J Mol Sci 14: 15931-15958, 2013.

44. Kodama T, Hikita H, Kawaguchi T, Saito Y, Tanaka S, Shigekawa M, Shimizu S, Li W, Miyagi T, Kanto T, et al: The Bcl-2 homology domain 3 (BH3)-only proteins Bim and bid are functionally active and restrained by anti-apoptotic Bcl-2 family proteins in healthy liver. J Biol Chem 288: 30009-30018, 2013.

45. Bubici $C$ and Papa S: JNK signalling in cancer: In need of new, smarter therapeutic targets. Br J Pharmacol 171: 24-37, 2014.

46. Calvo N, Carriere P, Martin MJ and Gentili C: RSK activation via ERK modulates human colon cancer cells response to PTHrP. J Mol Endocrinol 59: 13-27, 2017.

47. Kosako H and Kou M: Global Identification of ERK substrates by phosphoproteomics based on IMAC and 2D-DIGE. Methods Mol Biol 1487: 137-149, 2017.

48. Yao X, Liu H, Zhang X, Zhang L, Li X, Wang C and Sun S: Cell surface GRP78 accelerated breast cancer cell proliferation and migration by activating STAT3. PLoS One 10: e0125634, 2015.

49. Ishaq M, Kumar S, Varinli H, Han ZJ, Rider AE, Evans MD, Murphy AB and Ostrikov K: Atmospheric gas plasma-induced ROS production activates TNF-ASK1 pathway for the induction of melanoma cancer cell apoptosis. Mol Bio Cell 25: 1523-1531, 2014.

50. Hempel $\mathrm{N}$ and Trebak M: Crosstalk between Calcium and reactive oxygen species signaling in cancer. Cell Calcium 63: 70-96, 2017.

51. Hseu YC, Tsai TJ, Korivi M, Liu JY, Chen HJ, Lin CM, Shen YC and Yang HL: Antitumor properties of Coenzyme $\mathrm{Q}_{0}$ against human ovarian carcinoma cells via induction of ROS-mediated apoptosis and cytoprotective autophagy. Sci Rep 7: 8062, 2017.

52. Kim MO, Moon DO, Jung JM, Lee WS, Choi YH and Kim GY: Agaricus blazei extract induces apoptosis through ROS-dependent JNK activation involving the mitochondrial pathway and suppression of constitutive NF- $\kappa$ B in THP-1 cells. Evid Based Complement Alternat Med 2011: 838172, 2011.

53. Sakon S, Xue X, Takekawa M, Sasazuki T, Okazaki T, Kojima Y, Piao JH, Yagita H, Okumura K, Doi T, et al: NF-kappaB inhibits TNF-induced accumulation of ROS that mediate prolonged MAPK activation and necrotic cell death.EMBO J 22: 3898-3909, 2003.

This work is licensed under a Creative Commons Attribution-NonCommercial-NoDerivatives 4.0 International (CC BY-NC-ND 4.0) License. 